Vol 2, No. 1, Agustus 2019: 47 - 54, DOI: 10.34007/jehss.v2i1.56

\title{
Kecanduan Internet Ditinjau dari Kecerdasan Emosional Remaja di Warung Internet Kelurahan Sekip Medan
}

\section{Internet Addiction Judging from Emotional Intelligence of Youth in Warnet Sekip Medan Village}

\author{
Ferry*, Rianda Elvinawanty \& Yulinda S. Manurung \\ Program Studi Psikologi, Fakultas Psikologi Universitas Prima Indonesia, Indonesia.
}

Diterima: Mei 2019; Disetujui: Juli 2019; Dipublish: Agustus 2019

Corresponding: Ferrylieee@gmail.com

\begin{abstract}
Abstrak
Penelitian tersebut bertujuan untuk mengetahui hubungan antara kecerdasan emosional dengan kecanduan internet. Hipotesis yang diajukan dalam penelitian tersebut ada hubungan negatif antara kecerdasan emosional terhadap kecanduan internet dengan asumsi bahwa semakin baik kecerdasan emosional, maka semakin rendah kecanduan internet pada remaja, atau sebaliknya semakin buruk kecerdasan emosional, maka semakin tinggi pula kecanduan internet pada remaja. Subjek penelitian yang digunakan adalah 114 remaja di warnet Kelurahan Sekip Medan. Data diperoleh dari skala untuk mengukur kecanduan internet dan kecerdasan emosional. Analisis data menggunakan korelasi Product Moment (Pearson Correlation) dengan bantuan SPSS 20 for Windows. Hasil analisis data menunjukkan koefisien korelasi sebesar -0,737 dan signifikansinya sebesar $0,000(p<0,05)$. Hasil analisis data tersebut menunjukkan adanya hubungan negatif antara kecerdasan emosional dengan kecanduan internet. Hasil tersebut menunjukkan bahwa sumbangan yang diberikan variabel kecerdasan emosional terhadap kecanduan internet sebesar 54,3 persen, selebihnya 45,7 persen dipengaruhi oleh faktor lain yang tidak termasuk dalam penelitian. Berdasarkan hasil penelitian ini dapat disimpulkan bahwa hipotesis penelitian diterima, yaitu mempunyai hubungan negatif antara kecerdasan emosional dengan kecanduan internet.
\end{abstract}

Kata Kunci: Kecerdasan Emosional, Kecanduan Internet

\begin{abstract}
This study aims to determine the relationship between emotional intelligence and internet addiction. The hypothesis proposed in research is there any negative correlation between emotional intelligence with internet addiction on teenagers in internet café of Kelurahan Sekip Medan, assuming that the higher emotional intelligence, the lower the internet addiction, and vice versa. The subjects of this study were 114 teenagers in internet café of Kelurahan Sekip Medan. This research used emotional intelligence and internet addiction scale. Product Moment (Pearson Correlation) was used to analyze the correlation between two variable using SPSS 20 for windows. The results of the data analysis showed that the correlation coefficient was $-0,737$ with a significance value of $0.000(p<0.05)$. It shows there is a negative correlation between emotional intelligence with internet addiction. The results of this study indicate that the contributions made by the variable of internet addiction on personal adjustment was 54,3 percent, while the remaining 45,7 percent was influenced by other factors that were not examined. Baged on these results, it is concluded that the hypothesis, is acceptale, and there is a negative relationship between the emotional intelligence and internet addiction. Keywords: Emotional Intelligence, Internet Addiction
\end{abstract}

How to Cite: Ferry, Elvinawanty, R, \& Manurung, Y.S. (2019). Kecanduan Internet ditinjau dari Kecerdasan Emosi. Journal of Education, Humaniora and Social Sciences (JEHSS). 2 (1): 47 - 54.

\section{PENDAHULUAN}

Era globalisasi membawa perkembangan yang sangat pesat dalam ilmu pengetahuan dan teknologi. Teknologi yang dihasilkan telah mempermudah berbagai aktivitas manusia pada segala usia dan dalam semua aspek kehidupan. Khususnya berbagai teknologi dalam bentuk peralatan elektronik, gadget, dan smartphone yang semakin canggih mempermudah berbagai kalangan dalam mengakses internet dengan biaya yang terjangkau. Internet merupakan teknologi yang 
Ferry, Rianda Elvinawanty \& Yulinda S. Manurung, Kecanduan Internet Ditinjau dari Kecerdasan

sangat populer digunakan dewasa ini membuat internet terasa semakin penting dan luas cakupannya.

Internet menjadi sebuah pintu penghubung menuju dunia tanpa batas waktu yang membawa manusia untuk melihat berbagai hal dari semua belahan dunia. Lewat internet sesama pengguna jejaring sosial dari berbagai dunia, dipertemukan, saling berkomunikasi, saling berbagi, bertukar ide, dan bertukar pengetahuan. Dalam hal ini, internet menyediakan berbagai fitur media sosial yang dimulai dari Email, Friendster, Facebook, Twitter, Tumblr, Instagram, Skype, Path, BBM, LINE, Whatsapp, dan lain sebagainya. Media sosial ini dapat menyampaikan informasi yang diinginkan, hanya dalam beberapa detik menggunakan layanan internet. Tidak diherankan internet sangat digemari semua umur. Selain itu, internet juga menyediakan berbagai fitur seperti blog, game online dan berbagai website yang bermanfaat, sehingga internet wajar digunakan sebagai sarana pencarian informasi, forum diskusi, berbagi informasi, sarana ekspresi diri dan hiburan.

Namun sangat disayangkan dibalik begitu banyak dampak positif yang diberikan, internet juga memberikan banyak dampak negatif. Hal ini dikarenakan internet seringkali digunakan secara berlebihan, sehingga penggunaan internet menjadi tidak terkontrol dan menyebabkan dampak negatif, mulai dari segi kesehatan, psikologis hingga sosial. Semakin kembangnya perkembangan jaman sehingga semakin maju internet dari tahun ke tahun maka manusia semakin penasaran terhadap internet dan ingin mencari tahu tentang internet lebih dalam.

Internet berperan penting dalam memiliki informasi terbaru tentang setiap hal. Sehingga berita cepat tersiar dan berbagai informasi penting dapat diperoleh dengan cepat dan mudah. Hal ini mempermudah pelajar dan tenaga pendidik untuk mengikuti perkembangan di dunia pendidikan yang semakin pesat, yaitu berkembangnya ilmu pengetahuan melalui temuan-temuan dan berbagai eksperimen yang dilakukan. Penelitian ini bertujuan untuk mengetahui hubungan antara kecerdasan emosi dengan kecanduan internet.

Menurut Yoo, dkk., (dalam Barak, 2008), ditemukan bahwa remaja dengan kecanduan internet memiliki potensi yang lebih besar untuk memiliki masalah perilaku termasuk Attention Deficit Hyperactivity Disorder (ADHD), kecemasan/depresi, kenakalan (delinquent behavior), serta masalah seksual dan sosial. Sedangkan Suryani (2008) menjelaskan internet adalah hasil kemajuan teknologi yang mampu menyajikan segala macam ilmu pengetahuan di seluruh dunia tetapi disalah artikan oleh para remaja sehingga berdampak buruk bagi remaja.

Sedangkan menurut Kosasih (2011), kecerdasan emosional merupakan kemampuan yang dapat menggabungkan secara sadar pikiran, perasaan dan tindakan untuk bersahabat dengan diri sendiri dan orang lain. Adapun menurut Goleman (dalam Tridhonanto, 2010), kecerdasan emosional adalah suatu kemampuan yang dimiliki oleh seseorang dalam memotivasi diri, bertahan 
Vol 2, No. 1, Agustus 2019: 47 -54

untuk bangkit dari gagal, mengendalikan emosi dan menahan kepuasan, kemudian mampu dalam mengatur keadaan jiwa.

Salah satu contoh permasalahan pada remaja yang ada di lingkungan sekitar kita adalah kasus yang dialami oleh seorang remaja yang berumur 15 tahun dan berasal dari Bandung, yang bernama Dogol. Remaja tersebut sebagai tersangka atas pencurian sebuah sepeda motor yang berada dilokasi Kecamatan Andir. Tersangka mengaku hendak mencuri sepeda motor karena ingin main game online dan belakangan diketahui juga bahwa tersangka sering mengambil barang berharga dan uang milik orang tua tersangka di rumah hanya untuk bermain game online sehingga orang tua tersangka terpaksa menyimpan dompet di bawah bantal kamar tidur (www.news.detik.com).

Kasus lain yang terjadi pada seorang remaja di Tiongkok. Remaja yang berusia 19 tahun yang disebut sebagai Little Wang yang berasal dari Provinsi Jiangsu. Little Wang sengaja memotong tangan kirinya sendiri karena mengaku merasa frustrasi dan menekan keinginan untuk mengakses internet dan kemudian Little Wang menelepon taksi untuk diantarkan ke rumah sakit terdekat (www.liputan6.com).

Senada dengan kasus yang di atas, dialami juga oleh beberapa remaja di Tiongkok. Remajaremaja tersebut diduga kecanduan internet dan dikirim ke sebuah camp khusus pelatihan untuk mengatasi kecanduan terhadap internet yang berada di kota Fuyang. Tetapi camp tersebut menggunakan berbagai cara untuk menghentikan kecanduan internet, akhirnya menggunakan penanganan dengan bimbingan psikologis dan latihan fisik. Kemudian beberapa hari kemudian ada remaja yang dilarikan ke rumah sakit dan kemudian tewas, remaja tersebut mengalami lebih dari 20 luka eksternal dan beberapa luka internal dan kemudian para staf camp pelatihan ditahan oleh polisi dan camp tersebut diberhentikan (www.JawaPos.com).

Masalah yang dipilih dipandang layak untuk diteliti karena beberapa alasan yaitu semakin tingginya kecanduan internet pada remaja di Warnet Kelurahan Sekip. Tujuan penulisan artikel ini adalah mengetahui dan menganalisis hubungan antara kecerdasan emosional dengan kecanduan internet pada remaja di Warnet Kelurahan Sekip Medan di Medan.

\section{METODE PENELITIAN}

Sampel dalam penelitian adalah 114 orang pelanggan dari Warnet Satura, Marquee, dan Icafe, di Kelurahan Sekip Medan dalam rentang usia 12-19 tahun. Pemilihan sampel menggunakan metode purposive sampling. Pengumpulan data menggunakan pembagian dua skala, yaitu skala kecanduan internet dan skala kecerdasan emosional. Skala disusun dalam bentuk pernyataan dengan menggunakan Skala Likert.

Sugiono (2010) mendefinisikan populasi adalah wilayah generalisasi yang terdiri atas subjek yang mempunyai kualitas dan karakteristik tertentu yang ditetapkan oleh peneliti untuk dipelajari 
Ferry, Rianda Elvinawanty \& Yulinda S. Manurung, Kecanduan Internet Ditinjau dari Kecerdasan

dan kemudian ditarik kesimpulannya. Populasi penelitian ini adalah pelanggan warnet Kelurahan Sekip sebanyak 170 orang.

Metode pengumpulan data yang digunakan dalam penelitian dengan menggunakan metode pembagian skala untuk mengukur kecerdasan emosional dan kemampuan pemecahan masalah. Jenis skala menggunakan skala Likert. Dengan skala Likert, maka variabel dapat diukur dijabarkan menjadi beberapa indikator variabel. Kemudian indikator atau komponen-komponen tersebut akan dijadikan titik untuk menyusun aitem-aitem instrumen yang berupa beberapa pertanyaan atau pernyataan (Sugiyono, 2010).

Skala yang akan digunakan dalam penelitian tersebut menggunakan empat alternatif jawaban yaitu SS (sangat setuju), S (setuju), TS (tidak setuju), dan STS (sangat tidak setuju), pernyataan favourable maka mengandung nilai-nilai yang positif, SS (sangat setuju) diberikan bobot 4 (empat), S (setuju) dengan bobot 3 (tiga), TS (tidak setuju) dengan bobot 2 (dua), dan STS (sangat tidak setuju) dengan bobot 1 (satu). Sistem penilaian sebaliknya, jika ada pernyataan unfavourable yaitu SS (sangat setuju) diberikan bobot 1 (satu), S (setuju) dengan bobot 2 (dua), TS (tidak setuju) dengan bobot 3 (tiga), dan STS (sangat tidak setuju) dengan bobot 4 (empat).

Jenis validitas yang harus dipakai dalam penelitian adalah validitas isi. Validitas isi adalah validitas yang diestimasi lewat pengujian terhadap isi tes dengan data analisis rasional atau lewat profesional judgement (Azwar,2007). Validitas isi mengukur aitem-aitem tes yang mewakili komponen-komponen didalam keseluruhan kawasan isi objek yang akan diukur dan sejauhmana aitem-aitem tes dalam mencerminkan ciri perilaku yang akan diukur. Validitas isi tidak perhitungan statistik apapun melainkan hanya analisis rasional.

Dalam pandangan kuantitatif, suatu data dapat dinyatakan reliabel ketika dua atau lebih peneliti dalam objek yang sama menghasilkan suatu data yang sama, atau peneliti sama dalam waktu berbeda menghasilkan data yang sama, atau sekelompok data bila dipecah menjadi dua menunjukkan data yang tidak beda. Reliabilitas dijelaskan dalam koefisien, dengan angka diantara 0 sampai 1,00. Semakin tinggi suatu koefisien yang mendekati angka 1,00 berarti suatu reliabilitas alat ukur akan semakin tinggi. Sebaliknya reliabilitas alat ukur yang semakin rendah ditandai oleh suatu koefisien reliabilitas yang mendekati keangka 0 (Azwar,2007). Dalam penelitian ini uji reliabilitas menggunakan teknik Alpha Cronbach dengan menggunakan bantuan dari komputer program SPSS 20 for Windows.

Analisis data menggunakan suatu korelasi product-moment Pearson, dengan bantuan SPSS 20 for Windows untuk mengetahui hubungan antara variabel kecanduan internet dengan kecanduan internet. 


\section{HASIL DAN PEMBAHASAN}

Uji korelasi Product Moment merupakan uji korelasi parametrik, yaitu uji korelasi yang mensyaratkan bahwa data harus distribusi dengan normal dan distribusi data menunjukkan hubungan yang linier. Oleh karena itu, sebelum dilakukan analisis product moment, data yang terkumpul dahulu ditentukan normalitas sebaran dan linieritas hubungannya.

Dalam uji normalitas digunakan Kolmogorov Smirnov Test dengan cara melihat signifikansi data. Adapaun kriteria yang digunakan apabila $\mathrm{P}>0,05$ maka data berdistribusi normal dan sebaliknya jika $\mathrm{P}<0,05$ maka tidak berdistribusi normal. Sedangkan lineraritas dilihat dari nilai $\mathrm{P}$ yang diperoleh dari hasil SPSS. Jika $\mathrm{P}<0,05$ maka ada hubungan antara kedua variabel yaitu kecanduan internet dan prokrastinasi dikatakan linier, dan sebaliknya jika $\mathrm{P}>0,05$ maka hubungan kedua variabel tidak linier (Priyatno, 2010).

Hasil penelitian yang telah dilakukan terhadap 114 remaja yang berada di kelurahan Sekip Medan yang menjadi subjek penelitian, diperoleh bahwa terdapat hubungan negatif antara kecerdasan emosi dan kecanduan internet dengan koefisien korelasi Product Moment (Pearson Correlation) sebesar $r=-0,737$ dan nilai signifikansi p sebesar 0,000. Artinya semakin baik kecerdasan emosi yang dimiliki, maka remaja akan kurang kecanduan terhadap internet, semakin buruk kecerdasan emosi yang ada, remaja akan lebih sering kecanduan terhadap internet.

Pada penelitian ini diperoleh koefisien determinasi $R$ Square $\left(R^{2}\right)$ sebesar 0.543 . berdasarkan hasil tersebut dapat disimpulkan 54,3 persen kecerdasan emosi mempengaruhi kecanduan internet remaja Kelurahan Sekip Medan, sedangkan 45,7 persen dipengaruhi oleh faktor lain. Adapun faktor lain yang termasuk mempengaruhi kontrol diri dan prestasi belajar.

Hasil penelitian ini sejalan dengan yang dikemukakan oleh Suliswidiawati (2015) menyatakan bahwa terdapat titik dibelakang ubun-ubun yang merupakan titik untuk mengelola emosi, mengontrol emosi dan stabilitas emosi. Pengelolaan ini berfungsi untuk mengatasi takut, trauma, kecanduan dan depresi. Selanjutnya Hasil penelitian yang menyatakan adanya hubungan negatif antara kecerdasan emosi dan kecanduan internet searah dengan penelitian yang dilakukan oleh Souror, dkk., (2017) mengenai hubungan antara kecerdasan emosi dan kecanduan internet pada 75 siswa-siswi di Universitas Ahwaz. Dengan hasil $(r=-0,61 ; p<0,001)$, artinya apabila siswa memiliki kecerdasan emosi yang baik didalam dirinya, maka siswa tidak akan kecanduan terhadap internet, dan sebaliknya jika tidak terdapat kecerdasan emosi yang baik maka siswa cenderung akan kecanduan terhadap internet.

\section{SIMPULAN}

Berdasarkan hasil-hasil yang telah diperoleh dalam penelitian, kemudian dapat disimpulkan sebagai berikut: Ada hubungan negatif antara kecerdasan emosional dan 
kecanduan internet pada remaja pelanggan warnet dengan korelasi Product Moment (r) sebesar -0,737 dengan p sebesar 0,000 ( $<<0,05)$, artinya semakin baik kecerdasan emosi yang dimiliki, maka remaja akan kurang kecanduan terhadap internet, semakin buruk kecerdasan emosi yang ada, remaja akan lebih sering kecanduan terhadap internet.

Mean dari kecanduan internet pada subjek penelitian remaja di Kelurahan Sekip Medan menunjukkan bahwa kecanduan subjek penelitian lebih tinggi daripada populasi pada umumnya. Hal ini dilihat dari nilai mean empirik sebesar 71,31 lebih tinggi dari nilai mean hipotetik yaitu 65. Berdasarkan kategorisasi, dapat dilihat bahwa subjek yang memiliki kecanduan internet sedang adalah sebanyak 57 orang atau 50 persen dan subjek yang memiliki loyalitas tinggi adalah sebanyak 45 orang atau 39 persen. Sementara kecanduan internet rendah adalah sebanyak 12 orang remaja dengan nilai 11 persen.

Mean dari kecerdasan emosi pada subjek penelitian remaja di Kelurahan Sekip Medan menunjukkan bahwa subjek penelitian yang mendapatkan kecerdasan emosi lebih rendah daripada populasi pada umumnya. Hal ini dapat dilihat dari nilai mean empirik sebesar 62,67 lebih rendah dari nilai mean hipotetik yaitu 70. Berdasarkan kategorisasi, maka dilihat bahwa terdapat subjek dengan kecerdasan emosi yang rendah sebanyak 44 orang dengan 39 persen, sedangkan subjek memiliki kecerdasan emosi sedang adalah sebanyak 56 orang atau 49 persen, dan subjek memiliki kecerdasan emosi tinggi adalah sebanyak 14 orang atau 12 persen.

Hasil penelitian tersebut menunjukkan sumbangan efektif yang diberikan variabel kecerdasan emosi terhadap kecanduan internet adalah sebesar 54,3 persen, selebihnya 45,7 persen dipengaruhi oleh faktor lain yang tidak termasuk dalam penelitian seperti kontrol diri dan prestasi belajar.

\section{DAFTAR PUSTAKA}

Ali, M \& Asrori, M. (2010). Psikologi Remaja, Perkembangan Peserta Didik. Jakarta : PT Bumi Aksara. Arikunto, S. (2013). Prosedur Penelitian Suatu Pendekatan Praktik. Jakarta : Rineka Cipta.

Atamimi, M. \& Baskara, A. (2008). Kecerdasan Emosi Ditinjau Dari Keikutsertaan Dalam Program Meditasi. Jurnal Psikologi Vol. 35, No. 02 101-155. Diakses pada tanggal 2 Mei 2018 dari https://journal.ugm.ac.id/jpsi/article/view/7947/6145

Azwar, S. (2007). Realibilitas dan Validitas. Yogyakarta : Pustaka Pelajar

Azwar, S. (2011). Penyusunan Skala Psikologi. Edisi 2. Yogyakarta : Pustaka Pelajar.

Ekasari \& Nur. (2008). Hubungan Antara Konsep Diri Dengan Kecerdasan Emosional Pada Remaja. Jurnal Soul Vol. 1, No. 2. Diakses pada tanggal 13 April 2018 dari http://ejournalunisma.net/ojs/index.php/soul/article/download/717/641

Goleman, D. (2016). Emotional Intelligence Kecerdasan Emosional, Mengapa EI Lebih Penting Daripada IQ Cetakan Keduapuluh Dua. Jakarta: Gramedia. 
Hamid. (2004). EQ: Panduan Meningkatkan Kecerdasan Emosional. Penerbit : PTS Professional

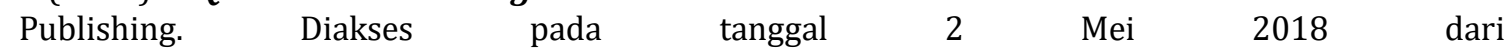
https://books.google.co.id/books?id=h1e7U4l_IksC\&printsec=frontcover\&dq=panduan+meningkat kan+kecerdasan+emosi\&hl=jv\&sa=X\&ved=0ahUKEwi1oYuSzoDbAhXDuo8KHedXDBcQ6AEILTAB\#v =onepage $\& \mathrm{q}=$ panduan $\% 20$ meningkatkan $\% 20$ kecerdasan $\% 20$ emosi $\& \mathrm{f}=$ false

Hurlock. (2002). Psikologi Perkembangan. Jakarta : Erlangga.

Jahja, Y. (2011). Psikologi Perkembangan Cetakan Pertama. Jakarta : Kencana.

Jong, W. D. (2002). Kanker Apakah Itu?. Jakarta : Arcan. Diakses pada tanggal 2 Mei 2018 dari https://books.google.co.id/books?id=cQbIgxZGFboC\&pg=PA38\&dq=kecanduan+merupakan\&hl=jv \&sa=X\&ved=0ahUKEwiNzKC0qHdAhVKfCsKHU_zACYQ6AEISDAF\#v=onepage\&q=kecanduan\%20merupakan\&f=false

Kusdiyati. (2012). Hubungan Antara Intensitas Dzikir Dengan Kecerdasan Emosional. Mimbar Vol. XXVIII,

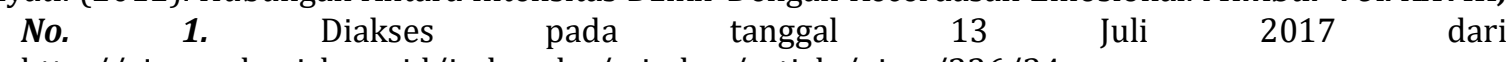
http://ejournal.unisba.ac.id/index.php/mimbar/article/view/336/34

Kosasih, H. (2011). Build The Best Of Your Life : Bimbingan Praktis Penerapan Emotional Intelligence Di Tempat Kerja. Jakarta : PT. Elex Media Komputindo.

Nggermanto, A. (2015). Kecerdasan Quantum. Melejitkan IQ, EQ, dan SQ. Bandung : Penerbut Nuansa Cendekia.

Nurmandia, H., Wigati, D., dan Masluchah, L. (2013). Hubungan antara Kemampuan Sosialisasi dengan Kecanduan Internet. Jurnal Penelitian Psikologi Volume 4 No 2. Diakses pada tanggal 14 April 2018 dari: http://jurnalpsikologi.uinsby.ac.id/index.php/jurnalpsikologi/article/view/17/

Papalia, D, E. (2008). Human Development. Psikologi Perkembangan. Jakarta : Kencana Prenada Media Group.

Santrock, J, W. (2003). Adolescence, Edisi Keenam. Jakarta : Penerbit Erlangga.

Saraiva, J., Esgaldo, G., Pereira, H., Monteiro S., Afonso, R, M., \& Loureiro, M. (2018). The Relationship Between Emotional Intelligence and Internet Addiction Among Youth and Adults. Journal of Addictions Nursing. $\quad$ Diakses pada tanggal $23 \quad$ April 2018 dari https://www.ncbi.nlm.nih.gov/pubmed/29505457

Sarwono, S. W. (2015). Psikologi Remaja Cetakan Ke-Tujuh Belas. Jakarta : PT Raja Grafindo Persada

Savitri, I. \& Efendi, S. (2011). Kenali Emosi. Jakarta : PT. Balai Pustaka. Diakses pada tanggal 1 Mei 2018 dari https://books.google.co.id/books?id=z8XGDAAAQBAJ\&pg=PR1\&dq=kenali+emosi\&hl=jv\&sa=X\&ve $\mathrm{d}=0$ ahUKEwjRi-OfoYjbAhXGUZQKHbieB_kQ6AEIJDAA\#v=onepage\&q=kenali\%20emosi\&f=false

Souror, N., Atyeh, C., Azadeh, S. (2017). Emotional Intelligence Anticipated And Its Relationship With Internet Addiction In Students Of Ahwaz University Of Medical Sciences. Journal of Medical Pharmaceutical And Allied Sciences. Diakses pada tanggal 19 Agustus 2018 dari jmpas.com/.../1493189139JMPAS_630_APRIL_778-783.pdf

Straussner, S. L. A. \& Brown, S. (2002). The Handbook Of Addiction Treatment For Women. San Fransisco : Jossey-Bass. $\quad$ Diakses pada tanggal $27 \quad$ April 2018 dari https://books.google.co.id/books?id=vPYNgHLGf-

$\mathrm{sC} \&$ printsec $=$ frontcover\&dq=The + Handbook + of + Addiction + Treatment + For + Women\&hl=jv\&sa $=X \&$ ved=0ahUKEwi1z-

OSpojbAhUFIZQKHY2iCkIQ6AEIJDAA\#v=onepage\&q=The\%20Handbook\%20of\%20Addiction\%20T reatment\%20For\%20Women\&f=false

Sugiyono. (2010). Metode Penelitian Kuantitatif Dan Kualitatif. Bandung : Alfabeta

Suliswidiawati, Y. (2015). Menggapai Hidup Bahagia. Jakarta : Elex Media Komputindo. Diakses pada $\begin{array}{llll}\text { tanggal } & 25 & \text { Agustus } & 2018\end{array}$ https://books.google.co.id/books?id=iE5JDwAAQBAJ\&printsec=frontcover\&dq=menggapai+hidup+ bahagia\&hl=jv\&sa=X\&ved=0ahUKEwjkjbej76fdAhUaTI8KHUivDzgQ6AEIJDAA\#v=onepage\&q=meng gapai $\% 20$ hidup $\% 20$ bahagia\&f=false

Suryani, L. K. (2008). Hidup Bahagia. Jakarta : Pustaka Obor Populer. Diakses pada tanggal 18 Agustus 2018 dari

https://books.google.co.id/books?id=v8RQTlowR5gC\&pg=PA113\&dq=remaja+internet\&hl=jv\&sa= X\&ved=0ahUKEwiDINbH0svdAhUSTI8KHWt4CJ0Q6AEIPjAE\#v=onepage\&q=remaja\%20internet\&f =false

Susilo, A. (2010). Teknik Cepat Memahami Keamanan Komputer Dan Internet. Penerbit : Elex Media $\begin{array}{lllllll}\text { Komputindo. } & \text { Diakses } & \text { pada } & \text { tanggal } & 25 & \text { April } & 2018\end{array}$ https://books.google.co.id/books?id=hEEp53lroZYC\&pg=PA35\&dq=kecanduan+game+online\&hl=j 
Ferry, Rianda Elvinawanty \& Yulinda S. Manurung, Kecanduan Internet Ditinjau dari Kecerdasan

v\&sa=X\&ved=0ahUKEwiPgszswdnaAhWIX5QKHQnQA0cQ6AEIJDAA\#v=onepage\&q=kecanduan\%2 0 game\% 20 online $\& \mathrm{f}=$ false

Timotius, K. H. (2018). Otak dan Perilaku. Yogyakarta : Andi. Diakses pada tanggal 24 Agustus 2018 dari https://books.google.co.id/books?id=y0JRDwAAQBAJ\&pg=PA224\&dq=kecanduan+merupakan\&hl= jv\&sa=X\&ved=0ahUKEwiNzKC-

0qHdAhVKfCsKHU_zACYQ6AEIMzAC\#v=onepage\&q=kecanduan\%20merupakan\&f=false

Vermaat, S, C. (2003). Discovering Computers. Jakarta : Salemba Infotek. Diakses pada tanggal 25 April 2018 dari

https://books.google.co.id/books?id=GRVvbCZb3cUC\&printsec=frontcover\&source=gbs_atb\#v=one page\&q\&f=false

Weisinger, H. (2000). Emotional Intelligence At Work. The Untapped Edge For Success. California : JosseyBass Inc. diakses pada tanggal 24 April 2018 dari https://books.google.co.id/books?id=6qNyYm2dyosC\&dq=Emotional+Intelligence+At+Work.+The+ Untapped++Edge+For+Success\&hl=en\&sa=X\&ved=0ahUKEwjVz-

fR1rndAhXEq48KHSgBCWAQ6AEIKTAA

West, R. \& Brown, J. (2013). Theory of Addiction: Second Edition. UK : Wiley Blackwell. Diakses pada tanggal 27 April 2018

dari

https://books.google.co.id/books?id=sWtwAAAAQBAJ\&pg=PT10\&dq=Theory+of+Addiction:+Secon $\mathrm{d}+$ Edition\&hl=jv\&sa=X\&ved=0ahUKEwiEpsn5pYjbAhWGQpQKHb_NDqIQ6AEIJDAA\#v=onepage\&q= Theory\%20of\%20Addiction\%3A\%20Second\%20Edition\&f=false

Wijanarko, J. \& Setiawati, E. (2016). Ayah Ibu Baik. Jakarta : Keluarga Indonesia Bahagia. Diakses pada tanggal 25 April 2018

dari https://books.google.co.id/books?id=RGPADQAAQBAJ\&pg=PA14\&dq=kecanduan+definisi\&hl=jv\&s $\mathrm{a}=X \&$ ved=0ahUKEwj8tryb1 NnaAhWBE5QKHaB2Ao0Q6AEIKjAB\#v=onepage\&q=kecanduan\%20def inisi\&f $=$ false

Zukav, G. (2006). The Seat Of The Soul. Jakarta : Pustaka Alvabet. Diakses 